\title{
Research on Perfecting Government Non-Tax Revenue Management System
}

\author{
Suhua Zhang, Zhuowen Huang \\ Nanfang College of Sun Yet-sen University, Guangzhou, China \\ Email: zhangsuhua_zsh@163.com, happyhzw@hotmail.com
}

How to cite this paper: Zhang, S.H. and Huang, Z.W. (2019) Research on Perfecting Government Non-Tax Revenue Management System. Open Journal of Accounting, 8, 35-46.

https://doi.org/10.4236/ojacct.2019.83003

Received: April 28, 2019

Accepted: July 28, 2019

Published: July 31, 2019

Copyright ( 2019 by author(s) and Scientific Research Publishing Inc. This work is licensed under the Creative Commons Attribution International License (CC BY 4.0).

http://creativecommons.org/licenses/by/4.0/

(c) (i) Open Access

\begin{abstract}
At present, China's fiscal revenue system consists of two important components. One is tax revenue and the other is non-tax revenue. With the continuous expansion of the scale of non-tax revenue and the phenomenon of irregular management, some non-tax revenue in China has become the main source of dismembering financial functions, reducing the efficiency of capital use, disrupting economic order and breeding corruption. Since the reform of non-tax revenue touches on the interests of those with vested interests and all parties have different views on the reform, it is difficult to reform non-tax revenue. As we all know, economy is related to a country's life and death. Economy is the top priority of the country. The development of the country depends on economic growth. However, many people ignore the impact of non-tax revenue on the economy, resulting in the country not making full use of non-tax revenue to achieve economic growth. Therefore, it is extremely important to study the non-tax revenue management system from the perspective of the impact of non-tax revenue on the economy. This paper focuses on the promotion and suppression of non-tax revenue to economic growth and puts forward some constructive suggestions on improving the management system of non-tax revenue.
\end{abstract}

\section{Keywords}

Non-Tax Revenue, Economic Growth, Management System

\section{Introduction}

At present, the influence of non-tax revenue on the economy is the main view in academia: Non-tax revenue plays a role in enhancing the national macro-control ability, mobilizing the enthusiasm of local governments and departments, making up for the shortage of financial budget funds, setting up public welfare and promoting local economic development. However, in the long run, it increases 
the burden on enterprises, disperses the financial resources of the government, and has a negative impact on economic growth [1]. Non-tax revenue and economic growth are inextricably linked. This paper will specifically analyze the promotion and inhibition of non-tax revenue on economic growth in China and put forward constructive measures to improve the management system of non-tax revenue.

\section{Theoretical Analysis of Non-Tax Revenue}

In order to discuss the problem of non-tax revenue, we should not isolate non-tax revenue, but conduct a systematic and comprehensive study on its concept, form and scale. By analyzing these basic elements of non-tax revenue, we can better improve the management system of non-tax revenue in China.

\subsection{The Concept of Non-Tax Revenue}

The term "non-tax revenue" first appeared in the official documents of the state in December 2001. Non-tax revenue refers to the financial funds obtained by governments, state organs, public institutions, social organizations acting as government functions and other organizations. Non-tax revenue is an important part of the government's financial revenue.

Non-tax revenue is a collection of different kinds of revenue. In different countries, the forms of non-tax revenue are also different. On the whole, however, whether in developed countries or developing countries, the non-tax revenue of various countries usually includes major forms, such as administrative fees, government funds, state-owned asset resources revenue, incomes from fines and confiscations, lottery public welfare funds and donations received in the name of the government, as shown in Table 1.

Table 1. Main forms of non-tax revenue in China.

\begin{tabular}{|c|c|}
\hline Non-tax revenue form & Concept \\
\hline $\begin{array}{l}\text { Administrative } \\
\text { fees }\end{array}$ & $\begin{array}{l}\text { State organs, public institutions, social organizations and other } \\
\text { organizations acting as government agencies collect fees from specific } \\
\text { clients in accordance with the principles of cost compensation and } \\
\text { non-profit in the process of providing specific services to citizens, } \\
\text { enterprises and other organizations. }\end{array}$ \\
\hline $\begin{array}{l}\text { Government } \\
\text { funds }\end{array}$ & $\begin{array}{l}\text { Governments and their subordinate departments, in accordance with the } \\
\text { provisions of laws and regulations, in order to support the development of } \\
\text { a specific industry approve the collection of financial funds with special } \\
\text { purposes from citizens, enterprises and other organizations. }\end{array}$ \\
\hline $\begin{array}{l}\text { State-owned asset } \\
\text { resources revenue }\end{array}$ & $\begin{array}{l}\text { As the owner of the property right, the government collects a kind of } \\
\text { property right income from the use of state-owned assets or the operators. }\end{array}$ \\
\hline $\begin{array}{l}\text { Income from fines } \\
\text { and confiscations }\end{array}$ & $\begin{array}{l}\text { The general designation of fines and confiscation of income refers to the } \\
\text { fines and confiscated money obtained by the departments. }\end{array}$ \\
\hline $\begin{array}{l}\text { Lottery public } \\
\text { welfare funds }\end{array}$ & $\begin{array}{l}\text { Special financial funds raised by the government through the issuance of } \\
\text { lottery tickets to support the development of public welfare undertakings. }\end{array}$ \\
\hline $\begin{array}{l}\text { Donations received } \\
\text { in the name of } \\
\text { the government }\end{array}$ & $\begin{array}{l}\text { Non-directional monetary donations received by governments, state } \\
\text { organs, public institutions, social organizations acting on behalf of the } \\
\text { government and other organizations in the name of the government. }\end{array}$ \\
\hline
\end{tabular}




\subsection{Scale Analysis of Non-Tax Revenue}

Since the reform and opening, the scale of non-tax revenue has been on the rise. Non-tax revenue has been on the rise, which means that non-tax revenue has become an important source of government revenue. However, in recent years, with the national tax reduction and fee reduction policy, non-tax revenue has declined.

From 2009 to 2018, the overall scale of national fiscal revenue was between 6000 - 200,000 billion Yuan, showing an upward trend (Figure 1).

Fiscal revenue consists of tax revenue and non-tax revenue. From 2009 to 2018, tax revenue increased overall, and non-tax revenue also increased from 896.2 billion Yuan in 2009 to 291.8 billion Yuan in 2016. In the past two years, non-tax revenue decreased, mainly due to the policy of fees and burden reduction which cancelled and cut down many non-tax items including reducing social security rates (Figure 2). In the past 10 years, non-tax revenue accounted for more than $10 \%$ of the fiscal revenue, and in 2016 the non-tax revenue accounted for nearly $20 \%$ (Figure 3 ).

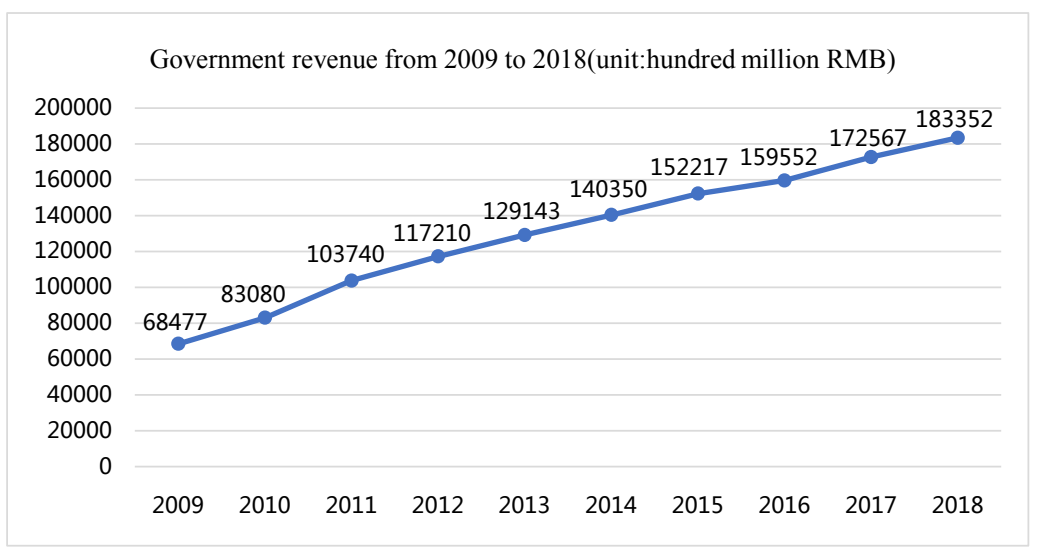

Figure 1. Government revenue from 2009 to 2018 (unit: hundred million RMB). Data source: Ministry of Finance of the People's Republic of China.

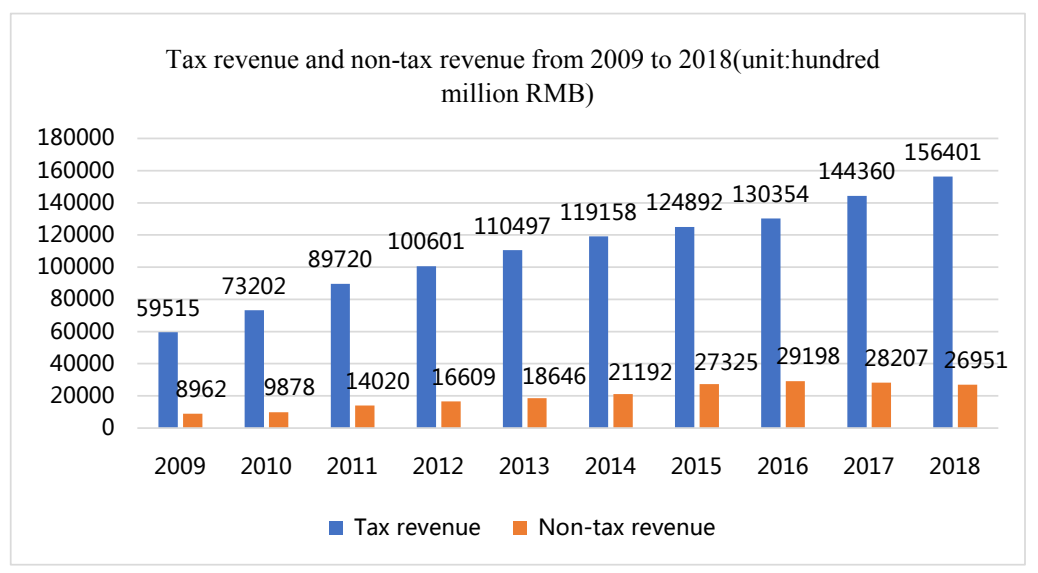

Figure 2. Tax revenue and non-tax revenue from 2009 to 2018 (unit: hundred million RMB). Data source: Ministry of Finance of the People's Republic of China. 


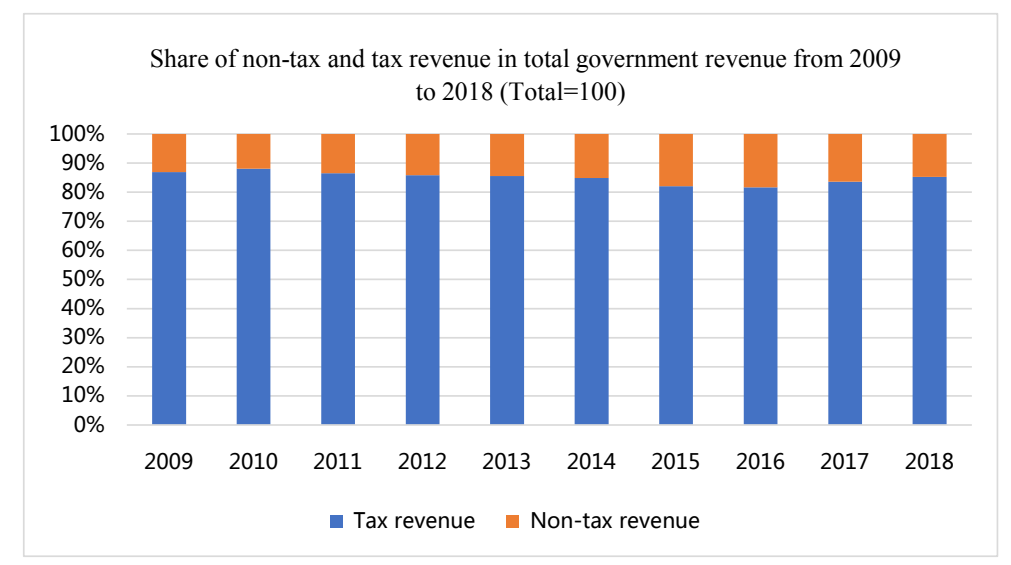

Figure 3. Share of non-tax and tax revenue in total government revenue from 2009 to 2018. Data source: Ministry of Finance of the People's Republic of China.

From 2008 to 2018, the national GDP rose from 348.51 billion Yuan to 90,030.9 billion Yuan (Figure 4). Among them, tax revenue and non-tax revenue have made certain contributions. The proportion of tax revenue in GDP is between $17 \%$ and $19 \%$, showing a trend of "rising first and then falling". The proportion of non-tax revenue in GDP is between $2 \%$ and $4 \%$, with fluctuations increasing and decreasing (Figure 5).

\section{Impact of Non-Tax Revenue on Economic Growth}

From the perspective of the mode of action, the impact of non-tax revenue on economic growth can be seen from two aspects: On the one hand, the government influences the behavior of economic subjects through the acquisition of non-tax revenue; On the other hand, expenditure through non-tax revenue exerts influence on the national economy. From the perspective of effect, government non-tax revenue can not only promote economic development, but also produce negative effects of interference or obstruction. Wang Qiao, a well-known scholar, believed that "GDP and government non-tax revenue are mutually causal" [2].

\subsection{Non-Tax Revenue to Promote Economic Growth}

As an important source of government financial funds, non-tax revenue provides a large amount of funds for the entire government system to perform its respective functions. Therefore, it plays a better role in promoting the implementation of the country's economic and social strategy, optimizing infrastructure and public services, promoting the economic system reform, and promoting the sustained, rapid and healthy development of the national economy.

\subsubsection{Accelerate the Development Process of Basic Industries}

According to the theory of economic growth, a country's rapid economic development must rely on relatively complete basic industries, and the development of basic industries often requires a huge source of funds, which cannot be met by 


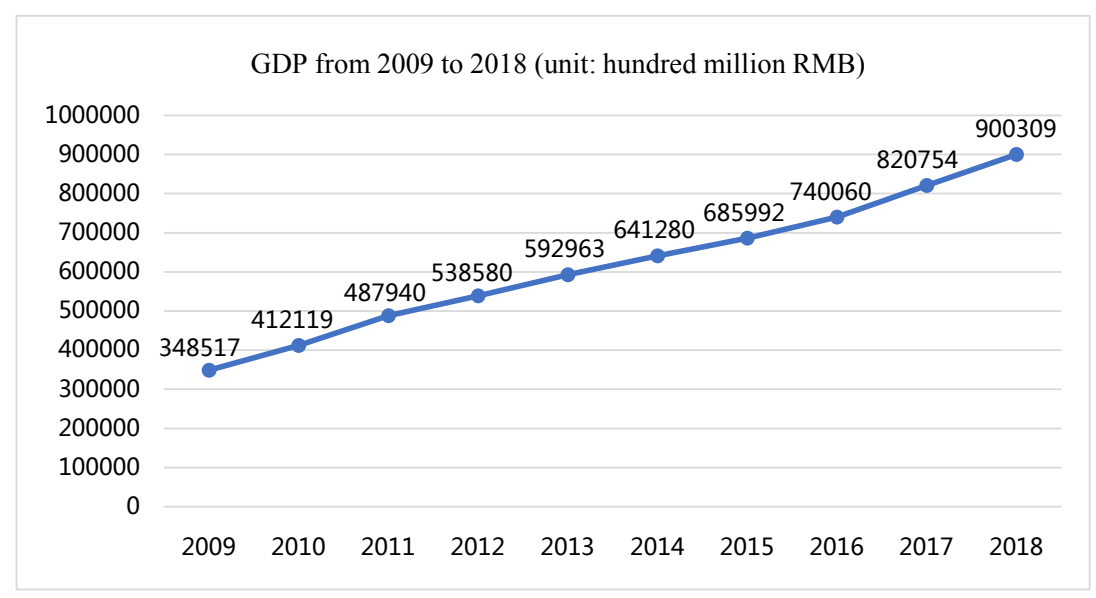

Figure 4. GDP from 2009 to 2018 (unit: hundred million RMB). Data source: Ministry of Finance of the People's Republic of China.

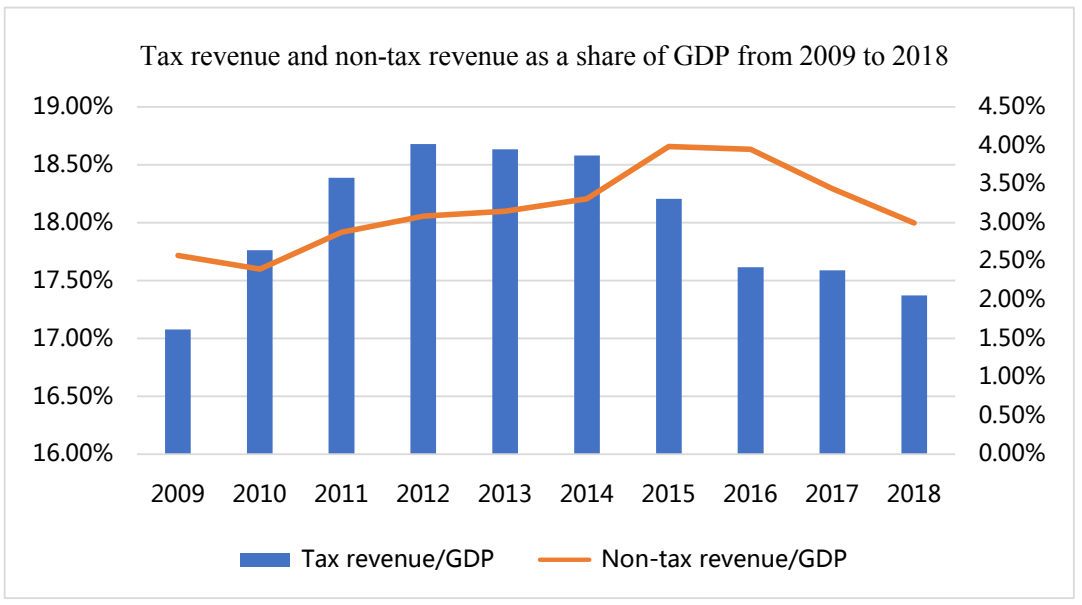

Figure 5. Tax revenue and non-tax revenue as a share of GDP from 2009 to 2018. Data source: Ministry of Finance of the People's Republic of China.

government tax revenue alone. Charges in government non-tax revenue and government funds provide a good source for them.

\subsubsection{Promote the Rapid Development of Education}

Endogenous economic growth theory holds that the accumulation of human capital and technological progress may break through the constraints of natural resources such as land and the decline of marginal productivity of capital, bringing about sustained economic growth [3]. The sustained and rapid development of the United States, known as the "new economic era", in the past 20 years has supported this theory. People are more and more firmly aware that human capital and technological progress play an increasingly important role in economic growth, and education is the most direct means to improve the quality of labor force and speed up technological progress. In addition, education also promotes social technological progress to spill over to social production by improving the quality of social members and the efficiency of social transactions. 
Education, as the foundation of a nation's progress and development, is the fundamental way to improve the overall quality and creativity of the whole nation. Since the reform and opening, under the condition of insufficient tax revenue, the state has set up education surcharges or fees both inside and outside the budget to raise necessary funds for education, effectively promoting the development of education. These fees mainly include: Rural education surcharge, education surcharge, local education surcharge, people's education fund, and study fees for students in non-compulsory education stage.

\subsubsection{Make up for Market Failure and Standardize Market Order}

A good market environment is an important factor for a country's sustained and stable economic growth. The government can make up for the deficiency of the market mechanism and standardize the market order through various fees and charges. Fees and charges can be used to measure and control the demand for specific types of services, realize the principle of benefits, reduce negative externalities, reduce pressure on taxes, and obtain monopoly profits. For the supply of public goods, the demand can be adjusted through the charging mechanism, making it possible to limit the demand to the social optimal level; for products with negative externalities, social costs can be compensated by charging. Congestion charges can be used not only to limit demand, but also to transfer demand from one time or place to another in order to make better use of existing facilities and reduce the need to generate additional capacity. In economic life, the production and operation of certain services and products have a typical nature of natural monopoly. If enterprises set their own prices, it is easy to harm the interests of consumers and hinder the improvement of efficiency, such as public welfare industries. For such products or services, the government should obtain monopoly profits or restrict the profits of enterprises through public pricing, weakening the control of the owners. The government, as the manager of the society, must use its administrative power to standardize and maintain the social and economic order and protect the public interest and public safety [4].

\subsubsection{Improve the Use Efficiency of Public Facilities and Optimize the Dynamic Allocation of Resources}

The government's use of the charging mechanism to provide public facilities is conducive to curbing waste and improving the dynamic allocation of resources. First, the scarcity of public resources can be transformed into a personal consumption cost, saving public expenditure. Because no matter what kind of product, as long as it is available free charge, people will generally not evaluate its value and determine the limit of moderate consumption, but will consume and possess it without restraint. The government's charging for certain public products can play a role in curbing waste. The second is to help plan public output and reduce blindness in public expenditure. Because the public goods provided by the government should ensure the necessary supply, which will be restricted by the government's financial resources. However, if the government charging system 
is implemented and management is strengthened, it will not only ensure the provision of public goods, but also ease the financial pressure of the government and help to improve the efficiency of public expenditure.

\subsection{Non-Tax Revenue to Inhibit Economic Growth}

With the rapid growth of government non-tax revenue mainly charged by administrative institutions, the negative impact of non-tax revenue on economic growth has gradually emerged and has a trend of spreading and expanding. It provides material conditions for the nonstandard and random behavior of governments. If non-tax revenue is allowed to expand and become irregular, it will definitely affect and hinder the implementation of the central government's overall decision-making and the effective implementation of macro-control. Local governments and departments will charge indiscriminately for setting up projects, setting standards and using them indiscriminately. The fees will be excessive and heavy. It will not only occupy the due share of tax revenue, but also increase the overall social burden on enterprises and people.

\subsubsection{Increase the Burden on Enterprises and Hinder the Formation of Capital}

The expansion of government non-tax revenue, which is the abnormal increase of various fees, will inevitably increase the burden on enterprises and erode the economic foundation. The expanded reproduction capacity of an enterprise is directly related to its burden, but its burden often comes not from taxes, but from various government fees.

Government fees correspond to public services. If the government charges too many and too many items, it will definitely alienate the charging function and lead to phenomena such as less service and more fees. In many cases, the purpose of charging is no longer to better serve or regulate specific economic behaviors, but to increase the interests of the charging department. The increase of non-tax burden on enterprises, on the one hand, reduces the profits of enterprises, affects the income of inherent assets, and weakens their ability to expand the scale of production and operation; on the other hand, these funds extracted from production are occupied by various charging departments of the government and are difficult to be regenerated into investment capital, which hinders the formation of capital and leads to sluggish economic growth. Moreover, the irregular charging behavior will definitely increase the uncertainty of the expected investment loss and expected return of social investors and worsen the investment environment [5]. This will reduce the formation of social capital in terms of increment, resulting in the loss of efficiency in the use of social capital.

\subsubsection{Diversify the State's Financial Resources and Weaken the Government's Macro-Control Capability}

The division of financial power and the dispersion of financial resources are im- 
portant features of our government distribution system. The expansion of non-tax revenue is an important reason for this pattern. According to the current financial system, China's non-tax revenue consists of two parts: budgetary funds and extra-budgetary funds. According to the principle of "the two rights (ownership and use right) remain unchanged", a considerable portion of non-tax revenue has been scattered among the revenue-collecting departments and separated from the financial system [6]. On the one hand, it has played a positive role in mobilizing the enthusiasm of various departments, units and localities, making up for budget funds and easing financial conflicts. On the other hand, it disperses the national financial resources and weakens the government's macro-control ability.

With the continuous expansion of government functions, the number of functional departments set up within the government is also increasing. The central government has dozens of functional departments and each department has its own independent financial resources and interests. Even after deducting the part included in the national budget and plan control, each department has a strong ability to raise funds and invest, forming a certain scale of funds.

\subsubsection{Encourage Local Governments to Blindly Construct and Distort the Industrial Structure}

The rapid expansion of local government's non-tax revenue is easy to encourage repeated construction and blind construction, resulting in convergence of industrial structure, serious waste of funds and decline in benefits, and at the same time aggravating the difficulty of national industrial structure adjustment. Under the fiscal decentralization system, local governments have the initiative to develop the local economy, which is due to the interests of local governments. It intensifies the structural contradictions of economic development and reduces the quality and efficiency of economic growth. For example, some local governments blindly borrow money to invest regardless of economic development conditions and their own affordability. However, investment projects started under the background of blind borrowing are often inefficient, and some even repeat construction. The date of completion is the time of loss, which not only cannot produce the "poverty eradication" effect, but also places a heavier debt burden on the local government and reduces the quality and efficiency of economic growth.

\subsubsection{Disrupte the Market Operation Mechanism}

In a market economy, the healthy operation of market mechanisms such as supply and demand, price and competition is based on standardized and unified market rules. If there are a large number of non-standard and non-uniform non-tax revenue behaviors besides tax revenue, it is bound to disrupt the operation of the market mechanism, distort the price formation mechanism, mislead the behavior of enterprises and individuals, make it difficult for enterprises and individuals to form reasonable expectations in production and operation, make 
scientific decisions impossible, make their production and operation activities deviate from the direction of the national industrial policy, intensify the contradiction between supply and demand, disrupt the operation order of the market economy, and affect the healthy and sustainable development of the economy. Moreover, under the background of the increasingly globalized economy and the gradual deepening of China's reform and opening, the non-standard non-tax revenue will interfere with the market operation mechanism, which will inevitably have a negative impact on China's introduction of foreign capital and its active participation in international market competition. It will also cause foreign investors to doubt and misunderstand China's investment environment and produce adverse international impacts. Therefore, the interference of arbitrary charges on the market mechanism will eventually reflect the economic and social environment through the behavior of enterprises and individuals and will have an impact on economic growth.

\section{Improve the Government's Non-Tax Revenue Management System}

According to the promotion and inhibition of government non-tax revenue on economic growth, it is especially important to improve the management system of government non-tax revenue.

\subsection{Reasonable Determination of Charge Standard for Non-Tax Revenue}

Charge standard is a core component of government non-tax revenue system. The value content it reflects is neither the private cost reflected by market pricing nor the social cost reflected by taxation. Market economy countries generally determine the charging standard for non-tax revenue based on the principle of "cost compensation". Learning from the experience of non-tax revenue management in market economy countries, China should follow the principle of cost compensation in determining the charging standard of government non-tax revenue. The standard should be formulated on the basis of marginal cost, and should take into account factors such as externality and demand elasticity. In addition, in order to follow the principle of social fairness and humanistic spirit, low-income people can also be given a low-price strategy, or "lifeline pricing method" which means low-price supply for consumption below a limited amount and normal prices charged for consumption above a limited amount to ensure that low-income people can also obtain basic public services.

\subsection{Perfect the Non-Tax Revenue Collection Management System}

The reform of non-tax revenue collection management system is an important part of the reform of China's financial treasury management system. In view of the outstanding problems existing in the current collection of non-tax revenue in China, such as poor management regulations, high charging standards, and a 
large number of collection subjects, the reform of the collection system of non-tax revenue should be strengthened in line with the requirements of the market economy to establish a reasonable collection order of non-tax revenue. This is not only an important measure to standardize and rectify the financial order but also an important content to build a public finance framework.

Because the non-tax revenue has the characteristics of big difference, scattered and many items. Its collection methods are also varied. Considering the current reality of non-tax revenue collection and management in China, we should cancel illegal projects, strictly increase the examination and approval of new projects, and include some fees that have tax features into the tax collection and management system. In addition, expanding the scope of non-tax revenue collection by banks and improving the system of non-tax revenue collection by banks are also important aspects of improving the management system of non-tax revenue collection.

\subsection{Strict Management of Non-Tax Revenue Bills}

Receipts for administrative fees and bills confiscated are the basis and premise for the management of all non-tax revenue. They are also the legal vouchers for the financial revenues and expenditures of the departments that collect and impose fines and the original vouchers for accounting. They are also the important basis for supervision and inspection by the financial, price, auditing and other departments. Charge bills are important means of non-tax revenue management. We should strengthen the management of current bills, standardize and expand the coverage of bills in a unified way, and make use of various media to introduce in detail the types of financial bills and their corresponding charging nature, charging scope and filling requirements. For those who do not use financial bills to charge or impose fines, the parties may appeal to the financial department for refunds with illegal charging bills. We will strengthen the inspection of fees and charges and give full play to the control role of the source of bills and charges.

\subsection{Accelerate the Informatization Process of Non-Tax Revenue Management}

The construction level of non-tax revenue management information system affects the process of standardized management of non-tax revenue to a certain extent. It is better to establish a high-tech service platform suitable for non-tax revenue management. Using modern information construction, relying on the revenue management system of the "Golden Finance Project", and taking into account the connection with other financial business management systems, a non-tax revenue management information system is designed and developed with the non-tax revenue supervision subsystem as the core, the bank collection subsystem as the front desk, the bill management subsystem, the accounting subsystem, the unit collection ledger subsystem, and the unit reconciliation query 
subsystem as the auxiliary, and the computer network management is implemented. That is to say, non-tax revenue will be managed online by using "manual receipt" and "electronic receipt" printed by computer. The "electronic receipt" is sent to the collecting bank, and the "manual receipt" is sent to the approved on-site collecting apartment. Clear payment procedures: The payer holds the "Notice of Payment" issued by the collecting apartment and goes to the collecting bank to make payment. After the bank receives the payment, it prints the "Electronic Receipt" to the payer. The information is immediately transmitted to the database of the non-tax revenue management department. The funds are deposited into the special financial account. The payer holds the "Electronic Receipt" and goes to the collecting apartment to handle the business. At the same time, it can inquire about the arrival of funds at any time by telephone. In terms of facilitating the collection of apartments: For each payment received by the collecting bank, a "electronic receipt" shall be printed by computer, and all information of the "electronic receipt" shall be immediately transmitted to the charging information database of the non-tax revenue management department. The collecting departments can inquire about the fund income of each charging item in each unit of the system at any time through the internet. For apartments with centralized charging time and a large number of payers, the collecting bank will collect the fees at home. For some collecting apartments that lack collecting means or have no collecting bank nearby, on-site collecting is allowed.

\section{Conclusions}

From the influence of non-tax revenue on economic growth, this paper discusses how to perfect the management system of government non-tax revenue combined with the latest situation of non-tax revenue. Although China's non-tax revenue has declined in recent years as a result of the country's tax cuts and fees reduction policies, its share cannot be ignored. Non-tax revenue has both promoting and restraining effects on economic growth. Therefore, to perfect the government's non-tax revenue management system, we should not forbid or allow it to expand huge. We had better reasonably determine the standard of non-tax revenue charges, improve the non-tax revenue collection management system, strictly manage non-tax revenue bills, and speed up the informatization of non-tax revenue.

Certainly, there are still some limitations in this paper. Firstly, this paper discusses non-tax revenue by qualitative analysis rather than quantitative analysis which perhaps can calculate a standard number of non-tax revenue in China. Secondly, this paper doesn't base on non-tax revenue management system of other countries. Some countries such as America have a series of perfect non-tax revenue law which can be studied by China.

\section{Conflicts of Interest}

The authors declare no conflicts of interest regarding the publication of this paper. 


\section{References}

[1] Wu, S. and Wang, Q. (2000) Negative Effects of Government Non-Tax Revenue and Its Rectification. Financial Science, No. 1, 100-103.

[2] Wang, Q. and Wang, Z. (2009) Empirical Analysis of the Impact of Government Non-Tax Revenue on Economic Growth. Contemporary Finance, No. 12, 30-35.

[3] Aghion, P. and Howitt, P. (1998) Endogenous Growth Theory. The MIT Press, Boston.

[4] Wolf, C. (1993) Market or Governments: Choosing between Imperfect Alternatives. The MIT Press, Boston.

[5] Sepehri, A. and Chernomas, R. (2001) Are User Charges Efficiency and Equity Enhancing? A Critical Review of Economic Literature with Particular Reference to Experience from Developing Countries. Journal of International Development, 13, 183-209. https://doi.org/10.1002/jid.726

[6] Wang, Q. (2011) Research on the Relationship between Government Non-Tax Revenue and Economic Growth. Science Press, Beijing. 